\title{
Conservation of tropical tree biodiversity through macropropagation by shoot cutting of raru (Cotylelobium melanoxylon), a highly utilized dipterocarp in North Sumatra, Indonesia
}

\author{
ARIDA SUSILOWATI ${ }^{1, \bullet}$, KANSIH SRI HARTINI ${ }^{1}$, DENI ELFIATI ${ }^{1}$, HENTI HENDALATUTI RACHMAT ${ }^{2}$, \\ YOSIE SYADZA KUSUMA ${ }^{3}$, M. ZULHAM EFENDI SINAGA ${ }^{4}$, TATI SUHARTATI ${ }^{5}$ \\ ${ }^{1}$ Faculty of Forestry, Universitas Sumatera Utara. Jl. Tri Dharma Ujung No. 1, Kampus USU, Medan 20155, North Sumatra, Indonesia \\ Tel./fax.: +62-61-8220605, ^email: arida_iswanto@yahoo.co.id, arida.susilowati@usu.ac.id \\ ${ }^{2}$ Forest Research, Development and Innovation Agency, Ministry of Environment and Forestry. Jl. Gunung Batu No. 5, Bogor 16610, West Java, Indonesia \\ ${ }^{3}$ Program of Tropical Silviculture, Department of Silviculture, Faculty of Forestry, Institut Pertanian Bogor. J1. Raya Dramaga, Bogor 16680, West Java, \\ Indonesia \\ ${ }^{4}$ Faculty of Mathematics and Natural Sciences, Universitas Sumatera Utara. Jl. Bioteknologi No. 1, Kampus USU, Medan 20155, North Sumatra, Indonesia \\ ${ }^{5}$ Departement of Chemistry, Faculty of Mathematics and Natural Sciences, Universitas Lampung. Jl. Prof. Sumantri Brodjonegoro No. 1, Bandar \\ Lampung 35141, Lampung, Indonesia
}

Manuscript received: 17 November 2019. Revision accepted: 23 January 2020.

\begin{abstract}
Susilowati A, Hartini KS, Elfiati D, Rachmat HH, Kusuma YS, Sinaga MZE, Suhartati T. 2020. Macropropagation by shoot cutting of raru (Cotylelobium melanoxylon), a highly utilized dipterocarp in North Sumatra, Indonesia. Biodiversitas 21: $724-730$. Cotylelobium melanoxylon (Hook.f.) Pierre, or locally named raru, is one of native tree species from North Sumatra that has many uses for its wood and medicinal purposes for anti-diabetic, anti laxative and blood coagulation. C. melanoxylon has been experiencing short supply due to its limited natural distribution, forest degradation, illegal harvesting for its wood and bark and uncertain fruiting seas on of the species. Along with these alterations, C. melanoxylon population has been decreasing. The objective of this research was to determine the effectiveness of $C$. melanoxylon propagation by shoot cutting. Randomized factorial design with 2 factors was employed in this research. The first factor (factor A) was the cutting media (i.e. topsoil only; topsoil and sand with proportion of 1:1 v/v), and the second factor (factor B) was commercial auxin addition (i.e. 1g/100cuttings; without auxin). The observed parameters were survival percentage, rooted percentage, number of primary and secondary root, length of primary and secondary root and root histology. The results showed that the interaction between media and auxin addition did not have any significant effect on all tested parame ters. The average survival percentage was $70-90 \%$ and rooting percentage was $50-90 \%$. Adventitious root formation on C. melanoxylon cutting was originated from cell differentiation on wounded area near cambium, followed by root primordia formation and root meristem formation. The success of artificial propagation technique for this species will provide basic practice of $C$. melanoxylon cultivation and may contribute to the effort of ex situ conservation for valuable and threatened tree species.
\end{abstract}

Keywords: Cotylelobium melanoxylon, raru, root ability, shoot cutting, vegetative propagation

\section{INTRODUCTION}

Cotylelobium melanoxylon (Hook.f.) Pierre, or locally named raru, is a small (less than $10 \mathrm{~m}$ ) to large-sized tree up to $50 \mathrm{~m}$ tall. They are frequently have twisted bole, sometimes cylindrical and straight, branchless for up to 30 $\mathrm{m}$ but often forking at lower height with diameter up to $160-200 \mathrm{~cm}$. The trees have small and rounded buttress roots. For a long time, C. melanoxylon's woods have been used as raw materials by local people in Tapanuli District, North Sumatera Province, Indonesia for constructing houses, bridges, and boats (Susilowati et al. 2019) because they have high quality and they are very durable and resistant to termites and teredos. Beside their wood, $C$. melanoxylon's bark is also used for the mixture of Bataknese alcoholic drink called 'tuak' to accelerate fermentation. The bark of $C$. melanoxylon contains ampelopsin $\mathrm{F}$., isoampelopsin $\mathrm{F}$, e-viniferin, vaticanol $\mathrm{A}$, E, G, lyoniresinol (Matsuda et al. 2009). The bark also contains flavonoids as antidiabetic, tannins and saponins compounds (Pasaribu et al. 2007) which are useful as an antimicrobial (bacteria and viruses) and potential endophytic fungi as a source for medicine (Hasanah et al. 2017). C. melanoxylon's leaves are also used to treat wounds by the local people. According to Soerianegara and Lemmens (1994), C. melanoxylon's leaves and bark are also used as anti-diabetic drugs, and as medicine to treat diarrhea and malaria. In Thailand, C. melanoxylon has been used in traditional Thai medicine as an astringent, antilaxative, and blood coagulation agent (Matsuda et al. 2009).

Different from other dipterocarp species, $C$. melanoxylon has specific geographic distribution because it is only found in Southeast Asia mainland (Thailand, Indonesia, and Malaysia). In Indonesia, C. melanoxylon can be found in Sumatera, Kalimantan, Maluku, and Papua. Particularly in North Sumatera Province, C. melanoxylon can be found in Central Tapanuli, Simalungun, dan North Tapanuli districts (Pasaribu 2007). The disjunctive distribution of this species has been also threatened by habitat fragmentation. Harvesting of its bark by illegally debarking and cutting woods without regeneration effort has decreased the population of this species (Susilowati et 


\section{al. 2019; Pasaribu 2007).}

Cotylelobium melanoxylon has uncertain fruiting and flowering seasons. According to Appanah and Turnbull (1998), seeds of dipterocarp are produced in large quantities in periods of mass flowering once every 3 or 4 years. These periods are short, irregular and unpredictable. The seeds have a short viability period, a few weeks at the most, and are difficult to store or called recalcitrant seed. C. melanoxylon's seed is also threatened by insect borers in their habitat. These conditions tend to cause the decline of C. melanoxylon's population every year. The IUCN red list has classified $C$. melanoxylon with the Latin name of $C$. melanoxylon into a status of least concern (Barstow 2019), indicating that a rapid effort is required to protect this species from extinction. Artificial propagation of the species is one of the efforts to conserve C. melanoxylon.

The availability of appropriate propagation techniques is a major constraint to the domestication of some forest trees widely used by rural communities, including $C$. melanoxylon. Vegetative propagation techniques are the first steps in tree species domestication, offering opportunities for avoiding the problem of recalcitrant seeds (Susilowati et al. 2018; Rachmat et al. 2018) and producing clones in large quantity of the ortet for conservation purpose (Leakey 2004). In many dipterocarp species, vegetative propagation can provide an uninterrupted supply of high-quality planting stock at times when wildlings may be scarce because of the time gap since the last mass flowering (Priadjati and Rayyan 1998). Using part of plant, such as roots, stems, shoots, and leaves, will produce new planting stocks with similar genetic materials to their parent plant. Vegetative propagation using shoot cutting technique also facilitates the threatened species (Susilowati et al. 2019). The successful vegetative propagation using shoot cutting method as the effort of species regeneration has been reported in some species, such as for rare and endangered tree species (Rachmat et al. 2018), Dipterocarpus cinereus (Subiakto and Rachmat 2015), Taxus sumatrana (Susilowati et al. 2019) and Dryobalanops sumatrensis (Susilowati et al. 2018). There is no information regarding the artificial propagation of the species, yet mother trees as natural regeneration sources have been experiencing serious threats and declining rapidly in the wild. Shoot cutting is a method of plant propagation that is technically easy to do. This method can provide planting stocks of rare and endangered species, including $C$. melanoxylon, regardless of unregularly fruiting season and the scarcity of the mother trees. Based on this information, the use of shoot cutting technique is also expected to be able to contribute to solve $C$. melanoxylon regeneration problems. Therefore, this research is conducted to assess the effectiveness of $C$. melanoxylon's propagation using shoot cutting technique.

\section{MATERIALS AND METHODS}

\section{Materials}

Approximately 1-year-old C. melanoxylon seedlings were collected from its natural population in Bona Lumban forests, Central Tapanuli-North Sumatra, Indonesia (Figure 1). Information on the seedling age was based on local people information and the previous latest fruiting season that fall one year becomes the exploration conducted. Bona Lumban forest is located in Tukka Sub-district, Central Tapanuli District, North Sumatra Province, Indonesia and covers an area of $6.80 \mathrm{~km}^{2}$. Central Tapanuli District has an average temperature of $26.40^{\circ} \mathrm{C}$ with the highest may reach up to $32.2^{\circ} \mathrm{C}$ while its lowest temperature is around $22.4^{\circ} \mathrm{C}$. The average relative humidity was $82.50 \%$ and rainfall at around $12.1 \mathrm{~mm} /$ year (BPS 2016).

The forest in Bona Lumban Village is located in two types of land status, which are Protection Forest (Hutan Lindung/HL) and area for non-forestry uses (Area Penggunaan Lain/APL). The location of $C$. melanoxylon's natural population in the Bona Lumban forest was generally hilly, with the distance among $C$. melanoxylon's seedlings were far enough (Figure 2). To overcome the difficulties during their handling and transportation, $C$. melanoxylon's seedlings were transported using bare-root technique. Bare-root technique has been reported to work for Dipterocarp family in order to overcome the long distance between cutting source and the greenhouse or nursery (Rachmat et al. 2018).

However, bare-root technique has some weaknesses. The risk of declining physiological quality of the seedling is substantially higher in bare-root than in containerized planting stock. It also requires a period of time for acclimatization. Due to this consideration, before they were used as cutting materials, the seedlings were initially conditioned in a greenhouse to avoid environmental stress due to differences in temperature and elevation between the research location and $C$. melanoxylon's habitat. After 2 weeks of conditioning, $C$. melanoxylon seedlings were subsequently selected based on their health criteria, stem and leaf conditions. Healthy seedlings were indicated by being pests and diseases free, having a single stem with fresh green leaf. The cutting media were topsoil, and topsoil and sand (in ratio 1:1). Commercial auxin powder was used to promote root formation capacity. Shading net, propagator box, cutting scissors and pot tray were also used as tools in this research.

\section{Methods}

Shoot cutting technique and preparation were done according to KOFFCO technique (Sakai and Subiakto 2007) with minor modification in misting technique (Susilowati et al. 2017; Susilowati et al. 2018). The cutting materials were taken from orthotropic branches and made between two leaf segments $(7-10 \mathrm{~cm})$. The cutting materials were then immediately stored in water container. The leaves were trimmed into half or one-third of their original size to reduce water loss and stimulated root initiation. The basal of cut surface of the cuttings were cutting sideways $\left(45^{\circ}\right)$. The cuttings were then repeatedly washed using sterilized water. Before being used as treatment, auxin powder was diluted into distilled water until forming a paste with concentration of $10 \mathrm{mg} /$ cuttings (Sakai and Subiakto 2007). 

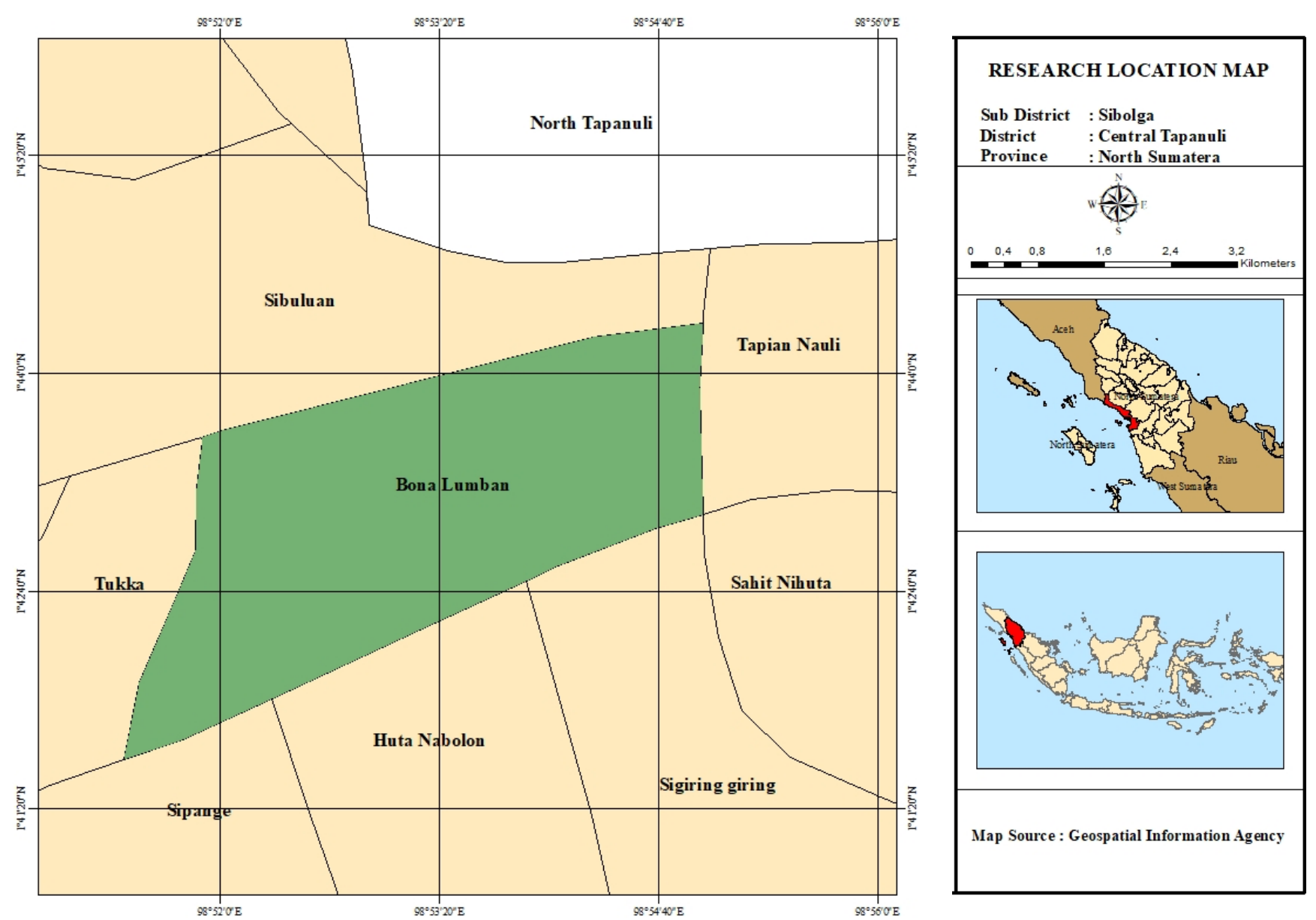

Figure 1. Cutting material (Cotylelobium melanoxylon) location in Bona Lumban Forest, North Sumatra, Indonesia

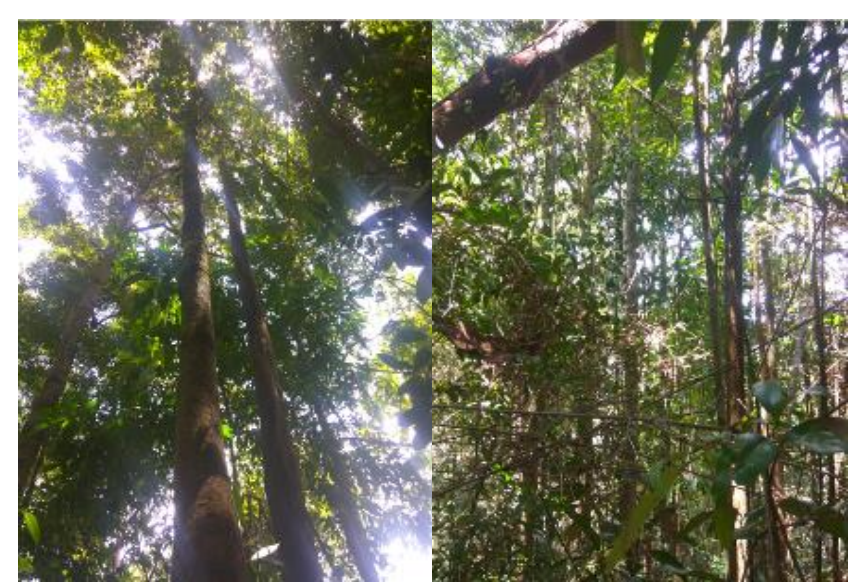

Figure 2. Cotylelobium melanoxylon tree and its natural population in Bona Lumban Forest, North Sumatra, Indonesia

The cutting materials were treated with commercial auxin paste then planted in pot-tray containing sterilized medium. All pot-rays with treated cutting were placed in propagation boxes according to the treatment. Watering was done twice in a week until 14 days after planting, once a week for 14 days-30 days after planting. Cuttings media were sprayed with fungicide (i.e. Dithane M-45) before planting, to prevent fungal attacks.

Completely randomized design with two factors was set on this cuttings experiment. The first factor was cutting media consisting of A1 (soil) and A2 (sand: soil). While the second factor was plant growth regulator (PGR) consisting of B1 (auxin addition) and B2 (control). All treatments were done with 10 replications. Observation was done at 12 weeks after planting using parameters of survival percentage, rooting percentage, primary and secondary root length, and primary and secondary root number. Monthly assessments of cuttings were carried out for five months, i.e. until no new roots were formed. Fallen, infected and dead cuttings were removed daily to avoid spreading of diseases. Frequent weeding (once in a week) was done to avoid competition with the cuttings for nutrients. At the end of each month, the number of rooted cuttings, and the number of roots and length of roots were recorded. ANOVA values were obtained using statistical software. 


\section{RESULTS AND DISCUSSION}

The effectiveness of cutting propagation is determined by the ability of root formation which varies within plant species. Some species show high rooting ability while others seem to have low ability of rooted cuttings. For dipterocarp species, Rachmat et al. (2018) stated that $67 \%$ of dipterocarps showed successful propagation through cutting techniques. The results of some cutting parameters of $C$. melanoxylon after 12 weeks are presented in Table 1. Until the end of observation, the cutting showed healthy indicators with new shoots and green leaves (Figure 3). The survival percentage of $C$. melanoxylon cutting varied from $70 \%$ to $90 \%$ and the rooting ability varied from $50 \%$ to $90 \%$ (Table 1). The high survival percentage and rooting ability of $C$. melanoxylon cutting in the end of observation could have resulted from the juvenility of cutting materials. Previous research conducted by Dumroese et al. (2011) demonstrated that the survival percentage, rooting ability, and the number of new roots and root lengths decreased as ramet ages increased. Cuttings from the juvenile parts of plant roots were much more easily done than those from adult plant tissues. Furthermore, Danu et al. (2011) stated that younger age of donor plants tended to contain high auxin and high $\mathrm{C} / \mathrm{N}$ ratio that resulted in high rooting percentage. Kontoh (2016) also stated that the high number of developed shoots and roots of species could be attributed to their physiological age or juvenility. Hartmann and Hansen (1958) stated that better rooting results were obtained from cuttings taken from young trees at approximately 2-10 years of age as compared to the cuttings taken from trees that were over 40 years old. $C$. melanoxylon cutting material was originated from 1-yearold ramet. It may be considered as the cause for higher survival and rooting percentage of $C$. melanoxylon cuttings. Furthermore, the presence of carbohydrates in the cuttings helped the growth and development of roots as well as sustained the cutting while it was in the medium. Wiegel et al. (1984) have also reported that carbohydrates also enhanced metabolic activities that occurred at the base of the cuttings to aid cell division which brought about root initiation.

The highest rooting ability was produced by cutting inserted into soil media and treated with auxin (90\%), while the lowest rooting ability was produced by cutting treated with soil media without auxin addition (50\%). Variance analysis (Table 2) showed that there were no significant $(\mathrm{P}>0.05)$ differences in interaction among media type and growth regulator, media and auxin addition, within all observed cutting parameters. The same findings were also found by Brodie (2003) in Dryobalanops oblongifolia and Susilowati et al. (2018) in Dryobalanops sumatrensis which stated that the interactions between media and exogenous auxin treatment did not influence the rooting ability of the cuttings and suggested that other factors (e.g. individual condition of plant stock) were more important for rooting. Aminah et al. (2006) also found that the juvenility of donor plants and cutting material diameters significantly influenced $S$. parvifolia and $S$. macroptera cutting compared to media and auxin treatment interaction.

According to Leakey (2014), rooted cutting depended on the optimization of both pre-severance and postseverance factors. Post-severance factors for stem cutting were important to be mediated by photosynthesis, respiration, transpiration and carbohydrate mobilization. The other factors were the role of growth regulators like auxins, cutting size, leaf area, and physiological water stress. The physical and chemical characteristics of the medium such as $\mathrm{pH}$, porosity, water holding capacity, and nutrient contents could be the factors stimulating root and shoot development. Physiological water stress was highly correlated with rooting media. These factors significantly influenced the rooting ability of stem cuttings of most ornamental plants. Generally, cutting inserted in soil media (A1) produces high value in cutting parameters (Table 1). The same results were also found by Magesa et al. (2018) i.e. red soil media produced the highest rooting percentage of the stem cuttings of hybrid coffee varieties. It might have resulted from the optimum moisture supply provided by the growing medium and the possible high carbohydrate to nitrogen ratio concentration in the cuttings. Another reason was that soil media had low $\mathrm{pH}$ of 4.0 and highest amount of micronutrients, such as iron, manganese, and zinc, which were known to stimulate rooting.

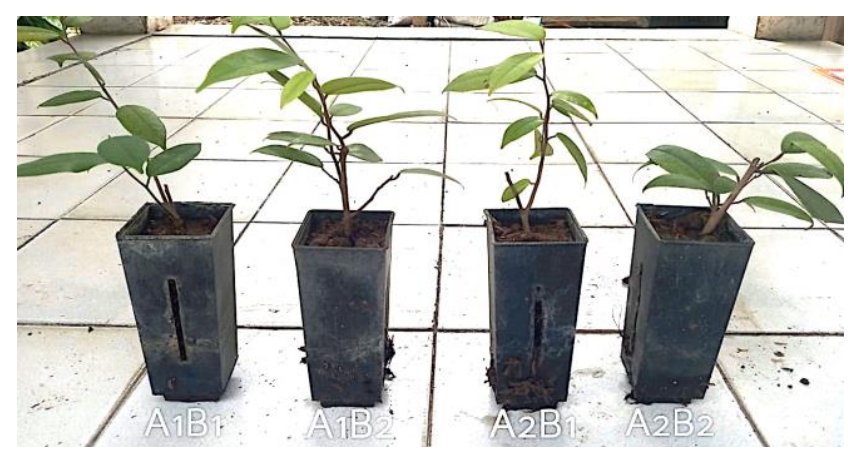

Figure 3. Cutting performance of Cotylelobium melanoxylon from different treatment after 12 weeks after cutting. A. A1B1, B. A1B2, C. A2B1, D. A2B2

Table 1. The average value of Cotylelobium melanoxylon shoot cutting parameters (12 weeks after cutting)

\begin{tabular}{lllll}
\hline \multirow{2}{*}{ Parameters } & \multicolumn{3}{l}{ Treatments } & \\
\cline { 2 - 5 } & A1B1 & A1B2 & A2B1 & A2B2 \\
\hline Survival percentage (\%) & 90 & 70 & 90 & 80 \\
Rooting percentage (\%) & 90 & 50 & 80 & 70 \\
Number of primary roots & 2 & 2 & 3 & 1 \\
Number of secondary roots & 30 & 41 & 21 & 17 \\
Primary root length & 5.4 & 6.4 & 3.2 & 6.1 \\
Secondary root length & 0.37 & 0.28 & 0.33 & 0.48 \\
\hline
\end{tabular}

Note: A1B1=soil media with auxin addition; A1B2=soil media without auxin addition; $\mathrm{A} 2 \mathrm{~B} 1=$ mixed soil and sand media with auxin addition; $\mathrm{A} 2 \mathrm{~B} 2=$ mixed soil and sand media without auxin addition 
Table 2. The summary of variance number of primary and secondary roots, length of primary and secondary roots

\begin{tabular}{lllc}
\hline \multirow{2}{*}{\multicolumn{1}{c}{ Parameters }} & \multicolumn{3}{c}{ Treatments } \\
\cline { 2 - 4 } & $\begin{array}{c}\text { Cutting } \\
\text { media }\end{array}$ & Auxin & $\begin{array}{c}\text { Cutting media } \\
\times \text { Auxin }\end{array}$ \\
\hline Number of primary roots & $0.796^{\text {ns }}$ & $0.098^{\text {ns }}$ & $0.446^{\text {ns }}$ \\
Number of secondary roots & $0.291^{\text {ns }}$ & $0.796^{\text {ns }}$ & $0.614^{\text {ns }}$ \\
Length of primary roots & $0.617^{\text {ns }}$ & $0.446^{\text {ns }}$ & $0.709^{\text {ns }}$ \\
Length of secondary roots & $0.599^{\text {ns }}$ & $0.837^{\text {ns }}$ & $0.438^{\text {ns }}$ \\
\hline
\end{tabular}

Note: ns = not significant at $5 \%$ level of probability

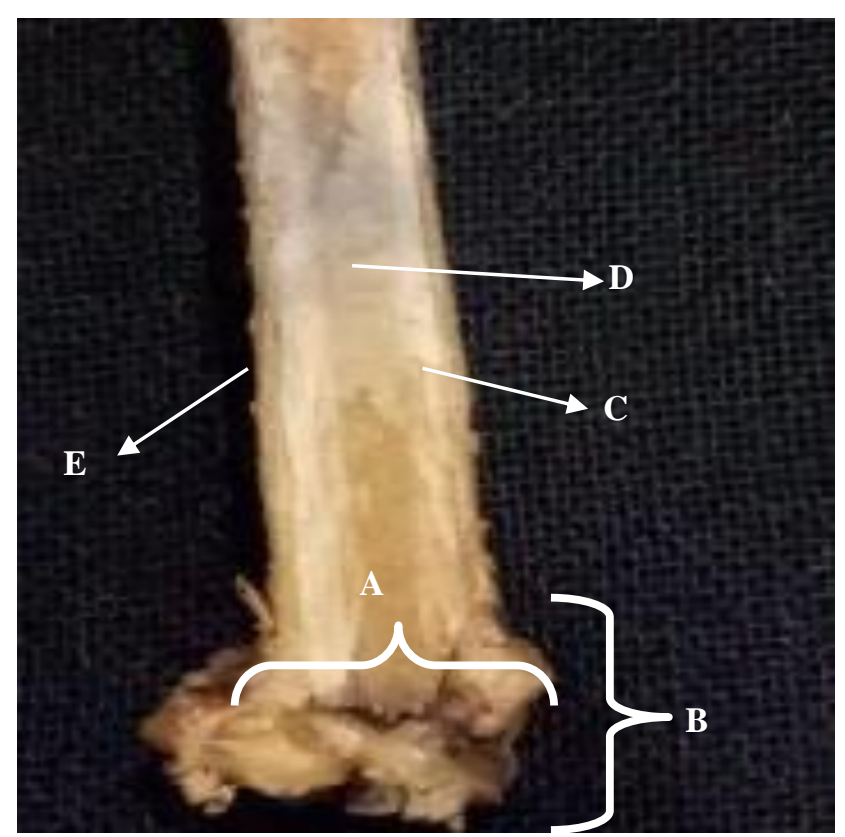

Figure 4. Root cross-section of Cotylelobium melanoxylon cuttings with 4.0x magnification. Note: A: basal of cut surface, B: roots zone, C: cambial zone, D: cortex, E: epidermis

Exogenous auxin treatment had been reported to increase the number of root primordia in the basal part of the cuttings, which led to increased rooting and root number. In this research, commercial auxin powder containing a mixture of auxins (IBA and NAA) was used. Davies and Haissig (1990) stated that mixtures of root promoting substances were sometimes more effective than either compound alone or adding a small percentage of certain phenoxy compounds to either IBA or NAA which increased rooting and produced root systems better than using phenyl compounds alone. Hormonal treatments had better-rooting responses than the control (without hormone). Auxins promoted starch hydrolysis and mobilized sugars and nutrients to the cutting base (Das et al. 1997). During cell division and auxin transport, auxins acted primarily through selective proteolysis and cell wall loosening with receptor protein transporting inhibitor response 1 and auxin-binding protein 1 (Da Costa et al. 2013). Although auxin influenced rooting ability of $C$. melanoxylon, this research also found that cutting without auxin treatment was also able to produce roots. The ability of root formation without auxin addition in dipterocarp species also has been previously reported by Aminah (1990). Juvenility might be an important factor in the rooting potential of dipterocarp cuttings (Kurniawan 2011). Juvenile tissues of woody plants tended to have higher levels of endogenous auxins and were less differentiated and therefore were more prone to re-differentiation (Hartman et al. 2002).

Rooting was maximized when the cutting was photosynthetically active and produced assimilates for the development and elongation of root primordia (Leakey 2014). Adventitious roots of some easy-to-propagate woody plants were formed in longitudinal rows along the stem, with the positions being related to the anatomy of the underlying vascular tissue (Hartmann et al. 2002). Based on the histological observation, root formation of $C$. melanoxylon cutting was started with callus formation on wounded area, followed by root primordia formation, and ended with the appearance of an adventitious root. Root primordia were found in vascular tissue, followed by roots elongation through the cortex or emergence through the epidermis, and formed the adventitious root (Figure 4). In a study of six Acacia baileyana F. Muell genotypes, Schwarz et al. (1999) found that roots were initiated in internal callus and that all genotypes had similar stem anatomies, whereas the ability to form adventitious roots varied with genotype.

Physiologically, there are two major types of root formation in stem cuttings, i.e. preformed and woundinduced roots. Preformed or latent roots are initially present during stem development and lying dormant until stem cuttings were made and placed in the proper environmental conditions for further development and emergence as adventitious roots (Hartmann et al. 2002). While woundinduced roots are the major type of auxin response factor (ARF) in stem cuttings. Once the stem (or shoot) was removed from the plant (wounding), a series of wound responses occurred and de novo adventitious root regeneration proceeded (Hartmann et al. 2002). In the wounded areas, sealing off of the wound (protection from desiccation and pathogens) occurred by the production of suberized, protective cells. Cells begin to divide, and a layer of parenchyma cells (callus) is formed in the wound area. De Klerk et al. (2011) summarized the successive phases in rooting of apple microcuttings as dedifferentiation, induction, outgrowth in the stem, and outgrowth from the stem. The initial phase, dedifferentiation, is the activation of cells (to become competent) by wounding related compounds and auxin. The induction phase is the initiation of cell division (to become committed) where auxin stimulated the formation of root meristemoids. During outgrowth in the stem phase, meristemoids develop into typical dome-shaped root primordia (to become determined), and at this stage auxin (exogenously applied) becomes inhibitory. Root primordia elongate and develop during the differentiation phase and finally grows out of the stem during the last phase of the adventitious rooting process.

Based on adventitious root type and root formation process, C. melanoxylon is classified into wound-induced 
type. Root formation was found in wounded areas. The process of wound-induced roots occurred immediately after cutting. In previous reports, it was determined that wound response signaling pathways were initiated at the base of the cutting (Schilmiller and Howe 2005), with a fast increase in jasmonic acid levels peaking $30 \mathrm{~min}$ after cutting (Rasmussen et al. 2015). The presence of this peak was correlated with adventitious root formation (Ahkami et al. 2009), and a short pulse of jasmonic acid increased adventitious root formation (Rasmussen et al. 2015). Adventitious root induction was promoted by high auxin and low cytokinin levels. Auxin levels could be regulated by biosynthesis, transport, conjugation, and degradation. Reductions in any of these also altered adventitious rooting (Ahkami et al. 2013). Auxin transport inhibitors significantly reduced adventitious rooting (Garrido et al. 2002).

In conclusion, one-year-old cutting materials of $C$. melanoxylon showed different rooting ability, ranging from 50 to $90 \%$. The cutting medium, auxin addition, and interaction between cutting medium and auxin addition did not significantly influence all observed parameters of $C$. melanoxylon cuttings. Juvenility considered being the highly important factor in the rooting potential of $C$. melanoxylon cuttings. Based on the histological observation, adventitious root of $C$. melanoxylonis classified into wound-induced roots. The process was initiated with callus formation on wounded area, followed by root primordia formation, and ended with the appearance of an adventitious root.

\section{ACKNOWLEDGEMENTS}

This research is supported by the Ministry of Research, Technology and Higher Education through scheme Penelitian Dasar Unggulan Perguruan Tinggi (PDUPT) grant number 234/UN5.2.3.1/PPM/KP-DRPM/2019. Much sincere gratitude goes to local farmers in Bona Lumban for their field assistance for this research.

\section{REFERENCES}

Ahkami AH, Lischewski S, Haensch KT, et al. 2009. Molecular physiology of adventitious root formation in Petunia hybrida cuttings: involvement of wound response and primary metabolism. New Phytol 181: 613-625.

Ahkami AH, Melzer M, Ghaffari MR, Pollmann S, Ghorbani Javid M, Shahinnia F, Hajirezaei MR, Druege U. 2013. Distribution of indole3- acetic acid in Petunia hybrida shoot tip cuttings and relationship between auxin transport, carbohydrate metabolism and adventitious root formation. Planta 238: 499-517.

Aminah H, Nor HRMN, Hamzah M. 2006. Effects of indole butyric acid concentrations and media on rooting of leafy stem cuttings of Shorea Parvifolia and Shorea macroptera. J Trop Forest Sci 18 (1): 1-7.

Aminah H. 1990. A note on the rooting of Shorea bracteolata stem cuttings. J Trop For Sci 3: 187-188.

Appanah S, Turnbull JM. 1998. A review of Dipterocarps: taxonomy, ecology, and silviculture. Center for International Forestry Research. Bogor.

BPS [Badan Pusat Statistik]. 2016. Kabupaten Tapanuli Tengah dalam Angka. Badan Pusat Statistik Kabupaten Tapanuli Tengah, Pandan [Indonesian]
Barstow M. 2019. Cotylelobium melanoxylon. The IUCN Red List of Threatened Species 2019: e.T33070A68069829. DOI: 10.2305/IUCN.UK.2019-1.RLTS.T33070A68069829.en.

Brodie JF. 2003. Factors affecting the rooting ability of Dryobalanops oblongifolia and Shorea splendida (Dipterocarpaceae) stem cuttings. J Trop For Sci 15 (1): 109-116.

Da Costa CT, de Almeida MR, Ruedell CM, Schwambach J, Maraschin FS, Fett-Neto AG. 2013. When stress and development go hand in hand: main hormonal controls of adventitious rooting in cuttings. Front Plant Sci 4: 133.

Danu A, Subiakto, Putri KP. 2011. Uji stek pucuk damar (Agathis loranthifolia Salisb.) pada berbagai media dan zat pengatur tumbuh. Jurnal Penelitian Hutan dan Konservasi Alam 8 (3): 245-252. [Indonesian]

Das P, Basak UC, Das AB. 1997. Metabolic changes during rooting in pre-grilled stem cuttings and air layers of Heritiera. Bot Bull Acad Sin 38: $1-4$.

Davies TD, Haissig BE. 1990. Chemical control of adventitious root formation on cuttings. Bull Plant Growth Regul Soc Am 18: 1-7.

De Klerk GJ, Guan H, Huisman P, Marinova S. 2011. Effects of phenolic compounds on adventitious root formation and oxidative decarboxylation of applied indoleacetic acid in Malus 'Jork 9'. Plant Growth Regul 63: 175-185.

Dumroese RK, Davis AS, Jacobs DF. 2011. Nursery response of Acacia koa seedlings to container size, irrigation method, and fertilization rate. J Plant Nutr 34: 877-887.

Garrido G, Guerreo JR, Cano EA, Acosta M, Sánchez-Bravo J. 2002. Origin and basipetal transport of the IAA responsible for rooting of carnation cuttings. Physiol Plant 114: 303-312.

Hartmann HT, Hansen CJ. 1958. Effect of season of collecting, indolebutyric acid, and pre-planting storage treatments on rooting of Marianna plum, peach, and quince hardwood cuttings. Proc Amer Soc Hort Sci 71: 57-66.

Hartmann HT, Kester DE, Davies FT, Geneve RL. 2002. Plant Propagation Principles and Practices. Prentice-Hall, New Jersey.

Hasanah U, Riwayanti, Idramsa, Prastya E. 2017. Molecular identification of endophytic fungi from bark of raru (Cotylelobium melanoxylon) that produce the antibacterial compound. Biosaintifica: 9 (3): 380386.

Kontoh IH. 2016. Effect of growth regulators and soil media on the propagation of Voacanga africana stem cuttings. Agrofor Syst 90 (3): 479-488.

Kurniawan B. 2011. Conventional propagation of several Aglaonema accessions using split single bud stem cutting. J Agrivigor 10 (2): 99104.

Leakey RRB. 2014. Plant cloning: macropropagation. In: van Alfen N. (eds). Encyclopedia of Agriculture and Food Systems. Elsevier Publishers, San Diego, USA.

Leakey RRB. 2004. Physiology of vegetative reproduction. In: Burley J, Evans E, Younqist JA (eds.). Encyclopaedia of Forest Sciences. Academic Press, London, UK.

Magesa JM, Msogoya TJ, Rweyemamu CL. 2018. Effects of growth media on rooting of stem cuttings of hybrid coffee varieties. Afr $\mathbf{J}$ Agric Res 13 (2): 41-46.

Matsuda H, Asao Y, Nakamura S, Hamao M, Sugimoto S, Hongo M, Yoshikawa M. 2009. Antidiabetogenic constituents from the Thai traditional medicine Cotylelobium melanoxylon. Chem Pharm Bull 57 (5): 487-494.

Pasaribu G, Bonifasius S, Gustan P. 2007. Analisis komponen kimia empat jenis kayu asal Sumatera Utara. Pusat Penelitian dan Pengembangan Hasil Hutan. Jurnal Penelitian Hasil Hutan 25 (4): 327-333. [Indonesian]

Priadjati A, Rayan. 1998. The effect of shading on the growth of Shore cf. Johorensis seeds in the nursery. Buletin Penelitian Kehutanan, Visi \& Misi Ilmiah BPK Samarinda 13 (1): 55-59. [Indonesian]

Rachmat HH, Subiakto A, Susilowati A. 2018. Mass vegetative propagation of rare and endangered tree species of Indonesia by shoot cuttings by KOFFCO method and effect of container type on nursery storage of rooted cuttings. Biodiversitas: 19 (6): 2353-2358

Rasmussen A, Hosseini SA, Hajirezaei M-R, Druege U, Geelen D. 2015. Adventitious rooting declines with the vegetative to reproductive switch and involves changed auxin homeostasis. J Exp Bot 66: 14371452.

Sakai C, Subiakto A. 2007. Pedoman Pembuatan Stek Jenis-jenis Dipterokarpa dengan KOFFCO System. Pusat Penelitian dan Pengembangan Hutan dan Konservasi Alam. Bogor. [Indonesian] 
Schilmiller AL, Howe GA. 2005. Systemic signaling in the wound response. Curr Opin Plant Biol 8: 369-377.

Schwarz Jl, Glocke Pl, Sedgley M. 1999. Adventitious root formation in Acacia baileyana F. Muell. J Hort Sci Bio 74, 561-565.

Soerianegara, Lemmens RHMJ. 1994. Plant Resources of South-East Asia 5. Timber Trees Major Commercial Timbers. Prosea, Bogor.

Subiakto A, Rachmat HH. 2015. Exploration, collection, and conservation of dipterocarps in Riau Islands. Pros Sem Nas Masy Biodiv Indon 1 (3): 428-433. [Indonesian]

Susilowati A, Hartini, KS, Rachmat HH, Alvaroby M. 2017. Propagation of valuable North Sumatra benzoin trees (Styrax sp.) using macrocutting technique. IOP Conf. Series, Mater Sci Eng 180 012046.

Susilowati A, Rachmat H Henti, Elfiati D, Kholibrina R Cut, Kusuma S Yosie and Siregar H. 2019. Population structure of Cotylelobium melanoxylon within vegetation community in Bonalumban Forest, Central Tapanuli, North Sumatra, Indonesia. Biodiversitas 20: 1681-87.

Susilowati A, Rachmat HH, Kholibrina CR, Hartini KS, Rambe HA. 2019. Propagation for conserving endangered taxol producing tree Taxus sumatrana through shoot cuttings technique. IOP Conf. Ser J Phys 1282: 012110. DOI: 10.1088/1742-6596/1282/1/012110.

Susilowati A, Rizlani CR, Rachmat HH, Aswandi, Raeni IM. 2018. Macropropagation - An important tool for conservation of North Sumatran endangered tree species, Dryobalanops aromatica. Biodiversitas 19 (5): 1672-1675.

Wiegel K, Horn H, Hock B. 1984. Endogenous auxin levels in terminal stem cuttings of Chrysanthemum morifolium during adventitious rooting. Physiol Plant 61: 422-428. 